STE VEN G OLD S I T H

\title{
Unbuilding Jerusalem
}

A P OCA L Y PSE A N D ROMANTIC

R E P R E S E N T A T I O N

\section{Cornell University Press}




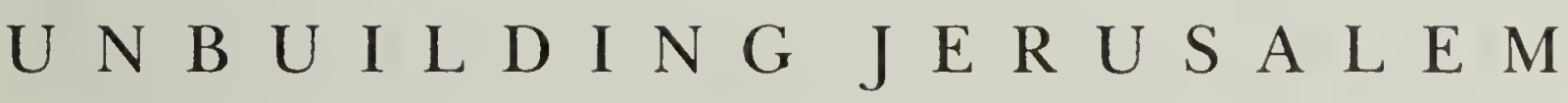


STEVEN GOLDSMITH

\section{Unbuilding Jerusalem}

A P OCALYPSE A N R OMANTIC

R E P RES E N T A T I O N

Cornell University Press

ITHACA AND LONDON 
Permission has been granted to reprint several lines from White Noise by Don DeLillo. Copyright (C) 1984, 1985 by Don DeLillo. Used by permission of Viking Penguin, a division of Penguin Books USA Inc., by permission of Picador, London, and by permission of the Wallace Literary Agency.

\section{Copyright $\mathbb{1} 1993$ by Cornell University}

All rights reserved. Except for brief quotations in a review, this book, or parts thereof, must not be reproduced in any form without permission in writing from the publisher. For information, address Cornell University Press, 124 Roberts Place, Ithaca, New York $1485^{\circ}$.

First published 1993 by Cornell University Press.

International Standard Book Number o-80 1 4-27 17-7 (cloth)

International Standard Book Number o-8o 1 4-9999-2 (paper)

Library of Congress Catalog Card Number 92-27066

Printed in the United States of America

Librarians: Library of Congress cataloging information

appears on the last page of the book.

(2) The paper in this book meets the minimum requirements of the American National Standard for Information Sciences-Permanence of Paper for Printed Library Materials, ANSI Z39.48-1984. 
To the Friends in Philadelphia, 1981-1986 
Digitized by the Internet Archive in 2018 with funding from

The Arcadia Fund 